\title{
Um marcador Macro-Jê de posse inalienável
}

\author{
Aryon Dall'Igna Rodrigues
}

A postulação de uma unidade linguística genética Macro-Jê, compreendendo a família Jê e várias outras famílias e línguas isoladas, tem um caráter altamente hipotético. As evidências lexicais são ainda muito poucas e as correspondências fonológicas, nelas baseadas, ainda necessariamente pouco elaboradas. Uma dificuldade especial para o trabalho comparativo está no fato de que várias famílias tidas como possíveis membros do tronco Macro-Jê tiveram todas as suas línguas extintas. Esse é o caso das famílias Kamakã, Purí (Coroado) e Karirí. Desta última, entretanto, há documentação mais ou menos ampla de duas línguas, mas das outras duas famílias e isolados linguísticos só recentemente têm sido publicados dados mais substanciais. Mesmo para a família Jê, que foi objeto de um primeiro ensaio de reconstrução fonológica com base em maior número de línguas e em maior quantidade de dados. O mesmo Davis (1968) publicou algumas correspondências fonológicas e lexicais entre o Proto-Jê, o Maxacalí e o Karajá. Rodrigues (1986) apresentou correspondências fonológicas (e lexicais) e nos marcadores de pessoa de doze famílias ou isolados. Num artigo mais recente (Rodrigues 1990) mostrou-se que as línguas Jê e o Kipeá (família Karirí) têm em comum um procedimento morfológico para marcar a contiguidade versus a não-contiguidade de um determinante sintático.

Uma evidência adicional do possível parentesco genético entre as famílias Jê, Maxakalí, Boróro e Karirí surge da verificação de que línguas destas quatro famílias não só têm em comum um mesmo processo sintático para exprimir a posse de objetos alienáveis mediante o uso de marcadores especiais, de significado mais ou menos genético, mas apresentam marcadores que têm toda aparência de terem um étimo comum. Nas línguas da família Jê tratase do morfema - , que ocorre em Panará (Kren-akarore) sob as formas yõ (com determinante contíguo) e sõ (determinante não-contíguo) (L. Dourado, c. p.), em Timbíra (Canela, Krahô) sob as formas yõ e hõ (mesma distinção) (Popjes e Popjes 1986:169) e no Kayapó sob as formas ñõ e $\tilde{o}$ (mesma distinção) (Wiesemann 1986:374). Exemplos do Canela: kapi yõ pur 'roça (pur) de 
Capi', hõ pur 'sua roça' (Popjes e Popjes 1986:169). Em Maxakalí o morfema correspondente é yõn, p. ex.: đ̃̄y yõy mĩkac 'minha faca (mîkac)'. Este morfema yõ $\eta$ tem as variantes õ $\eta$ e $\tilde{o}$, cuja distribuição ainda não está clara (Pereira 1992:27-8). Em Boróro há dois marcadores, um para animais domésticos, ako, e o outro para as demais posses alienáveis, $o$; exemplo deste último: in-o tori 'minha pedra (tori)' (Crowell 1977:177-8). O Boróro é uma língua que não tem vogais nasais (Crowell 1977:164 e Martins 1988:5, 15). A língua Kipeá (família Karirí) tem cerca de uma dezena de marcadores, quase todos começados por $u$-: ubá 'coisa dada', ubó 'fruta colhida verde para amadurecer', ubumaná 'planta', udé 'coisa cozinhada', upodó 'coisa assada', uitó 'coisa achada', etc.; p. ex.: dz-udé do giñé 'meus feijões (giñé) cozidos' (Mamiani 1877:60-61). É possível que u- seja um morfema cognato de õ da família Jê e de o do Boróro (o Kipeá não tem vogais altas nasais, Martins 1988:15), ao qual se acrescentaram outros morfemas mais específicos.

Embora ainda não estejam estabelecidas as correspondências vocálicas regulares entre os vários componentes do tronco Macro-Jê, pode-se aventar a hipótese de que o étimo dos marcadores de posse alienável das quatro famílias aqui examinadas tenha sido um morfema * o ou * ũ do Proto-Macro-Jê. 